\title{
BESZÁMOLÓ AZ EURÓPAI REGIONÁLIS TUDOMÁNYI TÁRSASÁG 48. KONGRESSZUSÁRÓL
}

\author{
(University of Liverpool, 2008. augusztus 27-31.)
}

\section{DUSEK TAMÁS - LUKOVICS MIKLÓS}

Az Európai Regionális Tudományi Társaság (European Regional Science Association - ERSA) 2008. augusztus 27. és 31. között az Egyesült Királyságban, Liverpoolban rendezte meg 48. kongresszusát. A rendezvényt az ERSA brit és ír szekciója, valamint a Liverpooli Egyetem (University of Liverpool) Városépitészeti Tanszéke közösen szervezte. Az ERSA-kongresszus résztvevőinek száma évröl évre nő, 2008-ban több mint 40 országból körülbelül 850 résztvevő érkezett a Mersey folyó partján fekvő városba, és több mint 750 tanulmányt regisztráltak.

A konferencia helyszínválasztása igazán telitalálat volt, többek között azért, mert 2008-ban Liverpool viselte az „Európa Kulturális Fövárosa” címet, így ebböl az alkalomból igen széles kulturális paletta állt a konferencia résztvevöinek rendelkezésére. A több mint 400 ezer lakosú nyugat-angliai város különösen híres a könynyüzenéről, hiszen Liverpool többek között minden idök egyik legsikeresebb együttesének, a Beatlesnek is a szülövárosa. John Lennon zenekara a mai napig a város életének részét képezi: szobrok, emlékhelyek, szórakozóhelyek, múzeumok, plakátok, buszdekorációk gondoskodnak a legenda továbbéléséröl. 2004-ben Liverpool vízparti látképe felkerült az UNESCO világörökség listájára, ezzel is jelezvén a város jelentőségét a világkereskedelemben és a dokk-technológiák fejlesztésében.

A konferencián a plenáris elöadásokon kívül négyféle szekciót szerveztek. A hagyományos szekciókban 90 perc alatt 3-5 elöadás hangzik el. A referált szekciókban 90 perc alatt három előadást tartanak, az egyes tanulmányoknak egy-egy kijelölt bírálója van, akinek a feladata a konferencia előtt elolvasni a tanulmányt és építő módon bírálni, javaslatokat tenni a továbbfejlesztésre. A harmadik típusú szekciók bizonyos témakörök köré szervezettek, a szekció szervezője által meghívott elöadókkal. A negyedik típusú szekciót a kongresszuson immár hagyományosan kiemelt figyelemben részesülő fiatal kutatók számára szervezik. A 33. életévüket a konferencia időpontjában be nem töltött kutatók április végéig beküldött tanulmányait témájuk elismert szakértője véleményezi, és a szervezők hosszabb időt hagynak a konferencia programjában az elöadáson elhangzottak megvitatására. A fiatal kutatók szekcióin szintén referált, bírálóval rendelkező eladások hangzanak el.

A konferencia - összefüggésben Liverpool „Európa Kulturális Fövárosa” címével - a „Culture, Cohesion and Competitiveness: Regional Perspectives” címet viselte. 
Ebből adódóan elsỏsorban az Európai Unió bövítésének hatásai, a területi egyenlőtlenségek dinamikájának kérdésköre, illetve a versenyképességi kutatások álltak elötérben, így az integráció, globalizáció, versenyképesség, regionális és városi növekedés, területfejlesztés stb. voltak a fö témakörök. A konferencia ezen felül olyan további kérdésköröket is felvetett, mint a környezetvédelmi politika, elérhetöség, közlekedési hálózatok, városi és vidéki térségek fejlesztése stb. Feltủnő továbbá, hogy a hazai tapasztalatokhoz képest a széles módszertani eszköztárat felvonultató elemzési témájú tanulmányok viszonylag nagyobb, míg a konkrét területfejlesztési kérdések viszonylag kisebb arányban jelentek meg.

A konferencia a címében meghirdetett, a szervezők kutatási érdeklődéséhez és a helyszín adottságaihoz közel eső tematikája mellett a regionális tudomány és határterületei valamennyi témakörében fogadott el jelentkezéseket. Így minden kutató az éppen aktuális kutatási témájával tud megjelenni a regionális tudomány legnagyobb, évente megrendezendő konferenciáján. Ez a tematikai kötöttség nélküliség jellemzi a regionális tudomány többi, évi rendszerességgel megrendezendő angol nyelvủ konferenciáját is (a Regional Science Association International tavasszal megrendezendö konferenciáját, a Regional Science Association brit és ír szekciójának augusztus harmadik hetében rendezett konferenciáját és a különféle északamerikai konferenciákat). Érdemes lenne elgondolkodni a Magyar Regionális Tudományi Társaság éves konferenciájának ilyen típusú, szük tematikai kötöttségektől mentes megszervezésén.

A konferencia érdemi programja általános kérdéseket tárgyaló plenáris előadásokkal indult. Ed Glaeser (Harvard University) előadása a városokban koncentrálódó jövedelmek és innovációk jelenségének magyarázatáról a jól ismert „távolság halála” nevủ szlogen köré épült. Az érdekes, inkább anekdotaszerủ elemekből felépülő elöadásban a szlogen használóinak többségéhez hasonlóan Glaeser sem tett említést a szállitási költségek termékfüggőségéről. Nehéz általában értelmezni és elfogadni az olyan kijelentéseket, mint hogy 1816-ban (általánosságban) a termékek 32 mérföldnyi szárazföldi szállítási költsége nagyobb volt, mint a termékek Atlanti-óceánon át történő szállítása. John Flamson (University of Liverpool) azt mutatta be, hogy a nyolcvanas évek eleji depressziót követően Liverpool milyen óriási változásokon, rekonstrukción esett keresztül. Sir Alan Wilson (University College London) a városi modellek történetét és azokat az új modellezési lehetőségeket tekintette át, amelyek az adatok bőségéből és a GIS használatából fakadnak. Tony Venables (University of Oxford) Afrika gazdasági helyzetével foglalkozott. Furcsa módon a fejlỏdést nagymértékben befolyásoló intézményi és kulturális háttér nem került szóba, míg például az előadó többször említette Afrika kicsi, sokszor tengerpart nélküli országokba osztódását és a városok túl kicsi méretét, mint a fejlődés hátráltatóját a piac kicsi volta miatt. A plenáris ülésen került sor a különféle regionális tudományi dijak átadására is. 
A tudományos program igen változatos tématerületek köré szerveződött. A tudományos előadások és tanácskozások három napon át 34 , elốre meghirdetett témakörben folytak:

- Kulturális megújulás és annak értékelése;

- Éghajlatváltozás és hatásai a városi és a regionális fejlődésre;

- A regionális politika bizonyíthatósága;

- A vállalkozások alapításának, átalakulásának és túlélésének regionális elemzése;

- Az európai régiók légi közlekedésének fejlödése;

- A munkaeró mobilitása a kibővített Európai Unióban;

- A folyómeder-menedzsment újraszervező szerepe;

- Területi célmeghatározás és a várospolitika;

- Területi információs rendszerek és területi elemzés;

- A fenntartható fejlődés lokális dimenziói;

- Globalizáció és regionális versenyképesség;

- Migráció, diaszpórák és fejlődés;

- Társadalmi kirekesztés, szegénység és tér;

- Rurális és lokális fejlődés;

- Dublin és Liverpool: a két város összehasonlítása;

- Hátáron átnyúló együttmüködés és fejlődés;

- Megújuló energia: a regionális fejlődés egyfajta lehetösége;

- A városi területek megújítása: elemzés, politika és értékelés;

- A regionális politika jövője Európában;

- Közegészségügy és regionális jólét;

- Térökonometria;

- Hosszú távú munkanélküliség és az elmaradott régiók;

- Új technológiák, innováció és a tér;

- Közpénzügyek és a regionális fejlődés;

- Fenntartható fejlödés és regionális gazdasági stratégiák;

- Területi gazdasági elemzés;

- Kiskereskedelem-fejlesztés és versenyképesség;

- Agglomeráció, klaszterek és politika;

- Városi és regionális marketing;

- A gazdasági tevékenységek és az emberek térbeli elhelyezkedése: új irányok;

- Városi és regionális kormányzás: a városrégiók szerepe;

- Infrastruktúra, közlekedés, mobilitás és kommunikáció;

- Tanuló régiók;

- A regionális tudomány új határterületei: elmélet és módszertan.

Örömteli, hogy évröl-évre egyre több magyar kutató elöadástervezetét és tanulmányát fogadják el az ERSA-kongresszusokon. 2008-ban hat magyar regionalista részvételét hirdette a programfüzet:

Tóth Géza (KSH) a „Közúti elérhetőség és a változó társadalmi-gazdasági folyamatok Magyarországon " címủ tanulmányában azt vizsgálta, hogy a közúti elérhetö- 
ség 2000 és 2005 között történt változása, valamint a társadalmi-gazdasági folyamatok között milyen kapcsolatok mutathatók ki, a változó elérhetőség hozzájárul-e, és ha igen, milyen mértékben az egyes térségek versenyképességéhez.

Budaházy György (Tomori Pál Főiskola) a regionális jövedelmek és termelés különbségéről tartott előadást, az általános részben a különféle módszertani és elméleti részeket áttekintve, majd konkrét magyarországi idősoros, megyei szintü adatokkal illusztrálva az elméleti kérdéseket.

Kukely György (MTA RKK) a magyarországi ipari szerkezetátalakulással foglalkozott. Előadásában így többek között kitért arra, hogy a rendszerváltást követően megjelent külföldi befektetők egy része az ezredfordulótól kezdve alacsonyabb bérköltségủ országokba helyezte át alacsony hozzáadott értékủ termelését. Ugyanakkor a magas hozzáadott értékủ termelők közül számosan felismerték a kvalifikált magyar munkaerőben, mérnöki tudásban rejlő lehetőségeket, és a termelés mellett kutató-fejlesztỏ részlegeket is létrehoztak, ennek révén a globális kutatás-fejlesztésben növekedett Magyarország szerepe.

Dusek Tamás (Széchenyi István Egyetem) előadásában az Új Gazdaságföldrajznak elnevezett kutatási irányzat térszemléleti és módszertani nehézségeit mutatta be. Így foglalkozott az egypontgazdaságok hálózatán alapuló megközelítés csapdáival, a gazdaságra vonatkozó, a valóságot nem leegyszerüsítő, hanem torzító, rendkívüli mértékben megszoritó feltevésekkel (például homogén munka, a szállítási költségek differenciálatlan kezelése a jéghegymodellel stb.). A kutatási irányzat nagyrészt figyelmen kívül hagyja a korábbi regionális kutatási hagyományokat (mint a német telephelyiskola vagy a regionális tudomány eredményei), sikeressége és népszerủsége ellenére megállapításai csak a mainstream közgazdaságtan számára tekinthetők újnak.

Dusek Tamás és Szalkai Gábor (ELTE) korábbi közös kutatásaik továbbfejlesztéseként előadásukban az időterek jellemzőit mutatták be, számos szempontból összehasonlítva a különböző típusú tereket, valamint érzékletes magyarországi példákat vázoltak a kérdés fontosságának illusztrálásra.

Dusek Tamás és Budaházy György közös előadása a területi árszínvonalak problémakörét feszegette, részben a koncepcionális statisztikai, módszertani és elméleti kérdéseket, a területi kérdések egypontszemléletből fakadó vizsgálatának buktatóit a területi árelmélet egy elemének, a vásárlóerőparitás elméletének térszemléleti hiányosságaival illusztrálva, részben pedig egy, a városi és falusi árszínvonalak különbségére irányuló felmérés eredményeit közölte.

Lukovics Miklós (Szegedi Tudományegyetem Gazdaságtudományi Kar) előadásában a területi különbségek komplex mérési lehetőségére mutatott be egy újszerủ megközelítést. A versenyképességi alapú eljárás segítségével lehetővé válik az, hogy a területi különbségek alakulását ne csak a hagyományos egy före jutó GDP-n keresztül kövessük nyomon, hanem komplex mutatószám-rendszer felhasználásával, többváltozós adatelemzési módszerek segítségével. Az EU standard versenyképesség definíciójára és a piramis-modellre épülő matematikai-statisztikai módszer empirikus alkalmazásának keretén belül a magyar kistérségek versenyképességének 
1998 és 2004 közötti változása került bemutatásra két alapvető, ám erre a célra még nem használt módszer, a klaszteranalízis és a többdimenziós skálázás segítségével.

A konferencia társadalmi programjai közül kiemeljük a záró fogadást, melyen a szervezők és az ERSA elöljárói méltatták a sikeres kongresszust. A Liverpooli Katedrálisban megrendezett impozáns vacsora közben lehetöség nyiltt a regionális tudomány múvelöi közötti kötetlen beszélgetésre és arra, hogy a résztvevők kellemes zene kíséretében gyönyörködjenek a világ legnagyobb orgonájában, mely az említett épületben található. A szervezök egy páratlan természeti kincs megtekintésére szerveztek fakultatív kirándulást, a résztvevők meglátogathatták az angol tavakat, ahol hajóúton vehettek részt a festôi szépségü vidéken.

A záró fogadáson jelentették be, hogy a 49. ERSA-kongresszusnak 2009. augusztus 25. és 29. között Łódź (Lengyelország) ad helyszínt. Az ez évi konferencia központi témája az Európai területi kohézió és az integratív tervezés lesz. A részletekről a 2009-es kongresszus honlapjăn olvashatnak: http://ersa.all2all.org/spip.php?rubrique2. Itt hívjuk fel a figyelmet arra, hogy a Magyar Regionális Tudományi Társaság (MRTT) tagság automatikusan ERSA tagságot is jelent, így minden MRTT tag jogosult az ERSA tagjainak járó minden kedvezményre. 